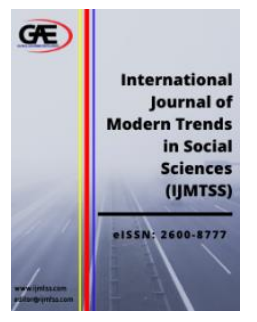

\author{
INTERNATIONAL JOURNAL OF \\ MODERN TRENDS IN \\ SOCIAL SCIENCES \\ (IJMTSS) \\ www.ijmtss.com
}

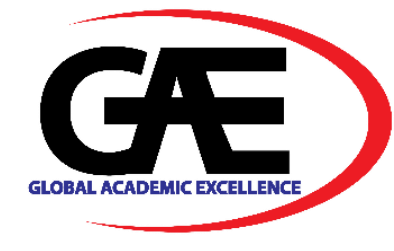

\title{
AN EVALUATION ON OUTCOME OF OIL PALM REPLANTING SCHEME (TSSPK) AND NEW PLANTING SCHEME (TBSPK)
}

\author{
Sheilyza Mohd Ishak ${ }^{1}$, Zaki Aman², Humaira Mat Taib \\ $1 \quad$ Malaysia Palm Oil Board \\ Email: sheilyza@mpob.gov.my \\ 2 Malaysia Palm Oil Board \\ Email: zaki@mpob.gov.my \\ $3 \quad$ Malaysia Palm Oil Board \\ Email: humaira@mpob.gov.my \\ Corresponding Author
}

\section{Article Info:}

Article history:

Received date:05.10.2020

Revised date: 10.11 .2020

Accepted date: 17.11.2020

Published date: 09.12.2020

\section{To cite this document:}

Ishak, S. M., Aman, Z., \& Taib, H. M. (2020). An Evaluation on Outcome of Oil Palm Replanting Scheme (TSSK) and New Planting Scheme (TBSPK). International Journal of Modern Trends in Social Sciences, 3 (14), 129148.

DOI: $10.35631 /$ IJMTSS.3140011

This work is licensed under $\mathrm{CC}$ BY 4.0 (c)

\begin{abstract}
:
The Oil Palm Assistance Scheme for Replanting (TSSPK) and the New Planting (TBSPK) for Independent Smallholders (ISH) were inaugurated in 2011 as part of the 10th Malaysia Plan. It is a subset of the National Key Economic Area (NKEA) Oil Palm Commodities Entry Point Project 1 (EPP1). Among the assistance included in these schemes are the high-quality seedlings, agricultural inputs such as fertilisers and pesticides along with the cash fund for land preparation and cultivation of the seedlings. The smallholders who participated in these schemes were also given extension services by the MPOB extension agent (TUNAS) on various aspects of oil palm management. A total of 382 participants were involved and responded to the survey. The proportion of respondents are from Sabah (38.5\%), Sarawak (38\%), and Johor (23.6\%). The study found that the average age of the participants mostly is 60 years old and above $(40.1 \%)$, and $57.4 \%$ of participants were the owner of the oil palm plantation. The range of fresh fruit bunch (FFB) production harvested for the first and second year is between $0-4.6 \mathrm{t} / \mathrm{ha} /$ year, which is slightly low due to the El Nino occurrence in 2016. A profit in income was recorded from the FFB sales after participating in the scheme. The low-income category recorded a decrease of $30.11 \%$ while the higher income category showed an increased between $2.66 \%$ to $16.59 \%$ after they joined the schemes. Some participants also implemented the integrated cash crops alongside the oil palm to generate income while waiting for the immature oil palm to produce yield. This study shows that most of the respondents complied with the Good Agriculture Practice (GAP) after joining the scheme. Most of the participants were pleased with the implementation of the schemes and services done by the TUNAS Officers and gave them an excellent rating. Several improvements are
\end{abstract}




\section{Introduction}

Year 2020 can be said to be a challenging year for most industries in the world due to the COVID-19 pandemic. It adversely affects demand and supply worldwide, with no exception of local industries. The Malaysia palm oil industry is also affected by this pandemic, where it experienced a slow demand from the local and the countries that imported palm oil. A series of Movement Control Order (MCO) had made it difficult for some regular upstream operations such as fertilisation, harvesting, FFB processing, and milling. This difficulty has created a shortage of labour and logistical problems, thus hindering the production of palm oil (MPOC, 2020)

In 2018, the oil palm sector was the fourth largest contributor to Malaysia's economy, accounting for RM 38 billion (USD 9.07 billion) of Malaysia's GNI. Considering that $16.9 \%$ of the oil palm planted areas were owned by the independent smallholders (ISH), indirectly ISH were potentially contributed to RM6.42billion (US $\$ 1.5$ billion) to the Malaysian GNI. The economic potential of oil palm has a significant contribution to improve the livelihood of many Malaysians, especially the ISH who reside in the rural area. Malaysia and Indonesia currently are responsible for over $85 \%$ of world oil palm production. The Palm Oil NKEA is aiming to gain a total of RM125 billion Gross National Income (GNI) contribution to exceed RM178 billion by 2020 . In order to achieve the target, an additional 41,000 jobs will be invented, 40 per cent of which will be highly skilled jobs earning an average monthly income of RM6,000.

Despite significant development in both oil palm plantation area and production, Malaysia is currently at the decisive point. The country started to realise that the limitations of suitable arable land and labour can affect the growth of the Malaysian oil palm industry. Also, the Malaysian oil palm industry is currently facing intense pressure from Non-Government Organisations (NGO's) against any further clearing on tropical forest land. Furthermore, the restriction on applying foreign labour also become a pressing and national debatable issue.

Therefore, in order to sustain, the oil palm industry needs to have a competitive edge over other competitors and produced at its maximum productivity. As suggested by Idris et al. (2001), accelerated replanting of oil palm represents a viable and sustainable option for the Malaysian oil palm industry to enhance its competitiveness. Oil palm replanting is one of the government's priority program to overcome the low replanting rate annually and the stagnation of FFB yield (hovering at an average of 18.7 tonnes/ha/year).

As included in the 10th Malaysian Plan, the government had allocated RM1.03 billion grants as an assistance scheme to smallholders for replanting and new planting of the oil palm tree. This allocation is one of the eight Entry Point Projects (EPP) or EPP1 under the National Key Economic Area or NKEA. The main goal is to replant the old oil palm trees that are no longer productive and produce a low yield (NTP, 2017). The implementation of EPP1 also included Copyright @ GLOBAL ACADEMIC EXCELLENCE (M) SDN BHD - All rights reserved 
the oil palm new planting for smallholders (TBSPK). Through the implementation of these two projects, it is targeted that the productivity of oil palm Fresh Fruit Bunches (FFB) yield, the acreage of oil palm plantation and the income of oil palm smallholders can be increased (MPOB, 2016).

Table 1 shows the scope and value of assistance under Replanting (Tanam Semula Sawit Pekebun Kecil - TSSPK) and New Planting Scheme for Smallholders (Tanam Baru Sawit Pekebun Kecil - TBSPK). It included a fund for land preparation, oil palm seedling, rock phosphate fertiliser, and other agricultural inputs for year 1 and 2 after planting. For Peninsular Malaysia, the value of the assistance scheme was RM 7,500 hectare ${ }^{-1}$, and for Sabah and Sarawak were RM9, 000 hectare $^{-1}$. The values of the assistance scheme for Sabah and Sarawak is $20 \%$ higher compared to Peninsular due to the higher cost of land preparation RM 4,000 hectare $^{-1}$.

Table 1: Scope and Value of Assistance Schemes

\begin{tabular}{|c|c|c|}
\hline \multirow[b]{2}{*}{ Scope } & \multicolumn{2}{|c|}{ RM hectare $^{-1}$} \\
\hline & Peninsular & $\begin{array}{c}\text { Sabah/ } \\
\text { Sarawak }\end{array}$ \\
\hline $\begin{array}{l}\text { 1. Fund for Land preparation } \\
\text { 2. Agricultural inputs; } \\
\text { - Oil palm seedlings and phosphate fertiliser, inputs for } \\
\text { control of the weed, pest and disease, and compound } \\
\text { fertilisers for year } 1 \text { and } 2 \text {. }\end{array}$ & $\begin{array}{l}2,500 \\
5,000\end{array}$ & $\begin{array}{l}4,000 \\
5,000\end{array}$ \\
\hline Total & 7,500 & 9,000 \\
\hline
\end{tabular}

Source: MPOB, 2016

Until $31^{\text {st }}$ December 2019, a total of 54,696 smallholders with 112,463 hectares had been supplied with oil palm seedlings for field planting. A total of 35,503.90 hectares is for replanting, and 76,959.12 hectares is for new planting. This replanting scheme will help to increase the FFB yield, thus will increase the income of the smallholders.

Although there is a special provision through the assistance program provided by, the participants must bear the cost of the balance. This scheme is only an incentive to ease the burden of ISH in the early stages of planting, yet the ISH must participate actively and accountable to maintain their oil palm during the non-economic period which is between 2 to 8 year.

This study was conducted with objective to evaluate the initial results for the first-year harvested yield (FFB) and the income of participants who have cultivated their oil palm in 2011 and 2012. Other information related on knowledge of Good Agriculture Practices (GAP) and the implementation of the scheme is also obtained through the survey which includes the integration of cash crops with oil palm, GAP and assessment of customer satisfaction level towards the services provided by the TUNAS Officers.

\section{Literature Review}

Oil palm trees generally reached maturity after three years of planting. While waiting for the maturity period, the producer will bear the cost of substantial capital outlay, which included non-recurrent cost, upkeep, and cultivation and fertiliser application. 
Previous research had demonstrated that crop integration with oil palm is the best way to address the issue of loss of income during the immature phase of oil palm after replanting. During the immature stage of oil palm, crop integration is convenient to be implemented. It involves planting cash or perennial crops. By proper planning, it could save the establishment cost such as land clearing, land preparation and construction of field drain as it will be accounted under oil palm development cost. Furthermore, the canopy of the cash crops will reduce light penetration to the ground; indirectly, the weeding cost also could be reduced (Fauziah, 2018).

The fertiliser is the most significant contributor, which involves $29 \%$ of the yield increment. It plays an essential role in the sustainability and profitability of oil palm, mainly when prices of commodities are uncertain, and the economics of farming has become the primary issue (Zaki, 2020). Nutrients absorbed by the palm tree will recede after the palm tree produced bunch FFB and the nutrient must be replaced to maintain the maximum production of FFB. The implementation of manuring work must be done effectively. The fertiliser should be applied at the actual rate per plant, the proper way, time and place. It was recommended that the manuring program need to be conducted when the weather is dry or when the rainfall is not too high.

Weeding is necessary to provide access to the palm for pruning, monitoring diseases, pests and harvesting. Weeds comprise of grasses, sedges, and broad leaves. The composition often changes according to the palm growth stages, which provide precise climatic and environmental conditions suitable for specific weed (Mohamad et al., 2010). There are several methods to manage weeds in oil palm plantation such as cultural, mechanical, integrated production systems of using livestock, or chemicals. (Hasnah et al., 2004). Weed management using chemical herbicides is the most common practice in oil palm plantation. Herbicides are an essential chemical in an oil palm plantation, particularly in weeding as weed is a vital component in the oil palm production systems.

In some instances, pesticides will be necessary to ensure profitable yields. Smallholders are always encouraged to use the right types of pesticides for effective control and reduce environmental impact. Pesticides should be used wisely based on the type of pest and on the right life cycles. Previous studies showed that there are several notable oil palm pests such as bagworms (Metisa plana and Mahasena corbetti), neetle caterpillars (Setora nitens), termites (Captotermes spp.) rhinoceros beetle (Oryctes rhinoceros), and rat (Rattus tiomanicus). The infestation of this pest has shown to affect oil palm production.

Harvesting is an important task to ensure that oil palm FFB could be harvest at the right time and its optimum quality. Harvesting criteria on MPOB GAP certification for smallholders to comply such as Harvesting around between 7 to 14 days, harvest only ripe FFB, keep bunch stalk short $<5 \mathrm{~cm}$, Collect all loose fruit and send FFB and loose fruits together/ mill within 24 to 48 hours.

The impact of agriculture practices on the environment is an emerging issue and becoming a global concern. The question is, what is the palm oil position concerning environmental critics? There is sufficient evidence recorded that the oil palm industry in Malaysia developed and adopted environmental and sustainable practices. The most applicable to the ISH is the Code of Good Agricultural Practices for Oil Palm Estates and Smallholding (MPOB CoGAP). Nevertheless, its implementation is voluntary. On $5^{\text {th }}$ September 2013, The Malaysia Standard Copyright $\odot$ GLOBAL ACADEMIC EXCELLENCE (M) SDN BHD - All rights reserved 
(MS) on Malaysian Sustainable Palm Oil (MSPO) was launched by The Deputy Prime Minister. All these sustainable certification guidelines were developed to address the global issue and to ensure oil palm remain competitive in the global market. A study conducted by Nur Hanani et al. (2016) showed that adoption of GAP practice among the 400 respondents was only $26 \%$. This result indicates that adoption of GAP practices would be a significant limitation for ISH to be certified since it is one of the criteria in the sustainable certification.

Extended dry weather below-average rainfall in the second half of 2015 due to El-Nino phenomenon and the first half of 2016 affected the production of the Malaysian oil palm industry in 2016 (Figure 1). The 2016 FFB yield was down 13.9 per cent to 15.91 tonnes per hectare compared to 18.48 tonnes per hectare in 2015 . Sabah reported a 14.5 per cent decline to 17.10 tonnes per hectare compared to 19.99 tonnes per hectare achieved in the previous year. The FFB yield for Sarawak was significantly lower at 14.86 tonnes per hectare; decreasing to 8.3 per cent compared to 16.21 tonnes per hectare in 2015 (Figure 1). For ISH sector, Sabah registered the lowest FFB yield as compared to the national FFB yield (Figure 2). Overall, the downtrend of oil palm performance in the year 2016 also affected the ISH, mostly the replanting and new planting participants.

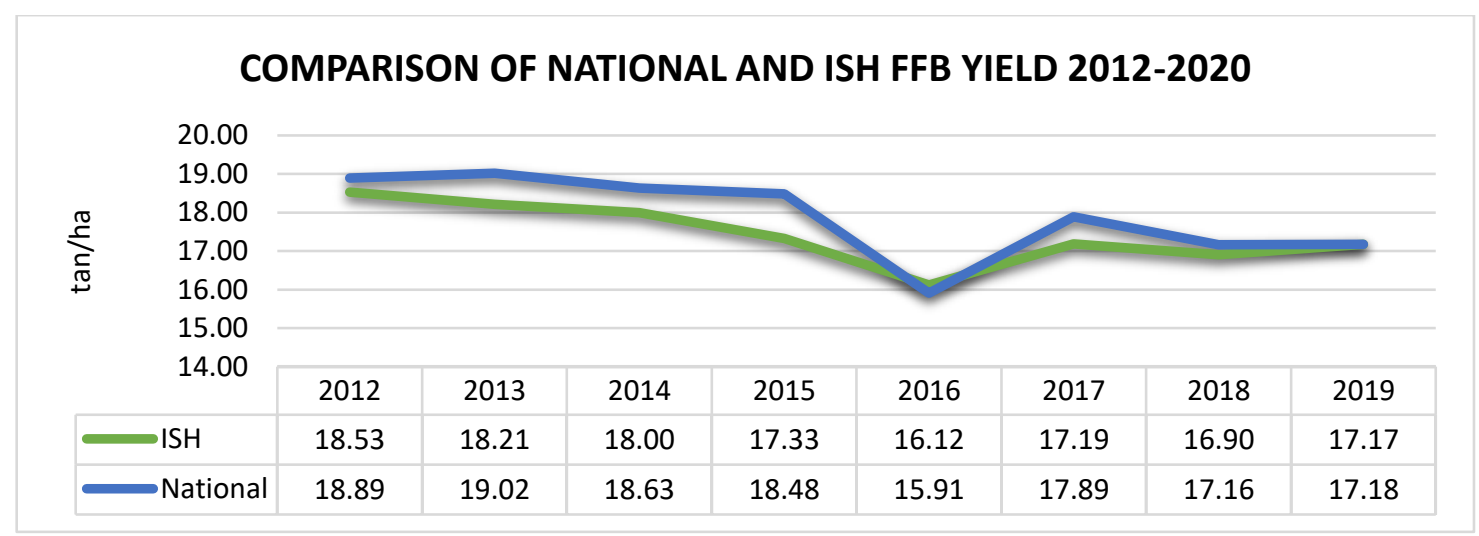

Figure 1: Comparison of National and Malaysian Oil Palm Independent Smallholders FFB Yield (2012-2019)

In the smallholder sector, the productivity of oil palm is affected by several factors such as agricultural extension services, farming practices, financial, soil types, climate and others. The agricultural extension can be described as a continuous process of delivering useful information to farmers and supporting them in obtaining the knowledge, skills and attitudes to use the information and technology effectively to improve productivity (Rahim, 2008 \& 2010).

The effectiveness of extension services is highly dependent on the ability of professional extension agents to be familiar their roles and application as the extension process on knowledge transfer relies heavily on them. In some countries, the extension projects are concerned with communicating national goals to rural areas. Rural areas are seen as very conservative, resistant to change and unaware of technological advances (Jasmin, 2013). 


\section{Methodology}

This study employed a quantitative approached. The questionnaires were applied to gather data from the interest groups. The study was conducted in 2016, and the data were analysed in 2017 using the SPSS. The study area was located in Johor, Sabah and Sarawak involving 382 smallholders who participated in the TSSPK and TBSPK schemes. The population of the study comprises of 8,901 TSSPK and TBSPK participants which planted in the year 2011 and 2012 and had received all the agriculture inputs (according to TSSPK Application Database, updated on Dec 2015). The age of their palm trees was between 1-2 years of harvesting when this study was conducted. The study has adapted its questionnaire from previous researchers.

The secondary data were gathered from the MPOB-IRED database and also from the previous related research. Proportionate sampling was used in this study. This method will allow the entire population of samples to have equal chances of being selected to be part of the study. In order to determine the appropriate number of the required samples, the G-Power analysis was employed. The analysis recommended sample size of 368 respondents. Four hundred questionnaires have been distributed to the respondents to avoid unreturned questionnaires. A total of 382 valid questionnaires were received and analysed.

\section{Result \& Discussion}

The data collection was divided into three phases. The first phase was conducted at Johor, which represents Semenanjung, the second stage was at Sabah, and the third stage was at Sarawak. A total of 382 smallholders have involved and responded to the survey that was conducted in June 2016 to December 2016. The proportion of respondents, according to schemes and states, was presented in Table 3.

Table 3: Proportion Of Respondents According To Schemes And States

\begin{tabular}{lcccc} 
TSSPK & 45 & 83 & 18 & 146 \\
\hline Scheme & Johor & Sabah & Sarawak & Total \\
\hline TSSPK & 45 & 83 & 18 & 146 \\
TBSPK & 45 & 64 & 127 & 236 \\
\hline Total & 90 & 147 & 145 & 382 \\
\hline
\end{tabular}

\section{Respondent Profile}

The results showed that the average smallholders who participated in the TSSPK and TBSPK Schemes were aged 60 years old and above $(40.1 \%)$, and most of them are secondary school leaver $(42.6 \%)$. From the total number of the respondents, nearly $57.4 \%$ of smallholders are full-time farmers and cultivated their oil palm plantation. However, there are also oil palm management works which were hired by the third party to harvesting FFB (27.3\%) weeding $(17.7 \%)$ and prepared the land (17.4\%). Age and knowledge of smallholders in carrying out the works is the main factor reason this decision was taken. Based on the experience in cultivating oil palm, the TSSPK participants have more experience $(21-30$ years; $34.2 \%)$ as they cultivated oil palm before replanting as compared to TBSPK participants (1-10 years; $73.3 \%$ ). This results suggested that the TSSPK participants were more successful in the management of oil palm after they joined the schemes. The main finding of this study also showed that the oil palm was the primary source of income of the participants $(50.8 \%)$, and they mainly depend on it (57.9\%). Further details of the results are as in Table 4 
Table 4: Demographic Profile of The Respondents

\begin{tabular}{l}
\hline Items \\
\hline Race \\
Malay $(24.6 \%)$ \\
Chinese $(7.9 \%)$ \\
Bumiputera Sabah $(33.0 \%)$ \\
Bumiputera Sarawak $(30.9 \%)$ \\
Others $(3.7 \%)$ \\
Age of ISH \\
$<20$ years $(0 \%)$ \\
$20-29(2 \%)$ \\
$30-39(8.3 \%)$ \\
$40-49(22.3 \%)$ \\
$50-59(27.2 \%)$ \\
60 and above $(40.1 \%)$ \\
Education Level \\
No formal education $(19.8 \%)$ \\
Primary school $(33.6 \%)$ \\
Secondary school $(42.6 \%)$ \\
College/Univerisity $(4.0 \%)$
\end{tabular}

\section{Another source of income}

None $(57.9 \%)$

Government employee $(6.7 \%)$

Private sector employee $(5.6 \%)$

Self-employed (29.8\%)

\section{Farm management}

Own $(57.4 \%)$

Contract $(17.6 \%)$

Both $(25.0 \%)$

\section{TSSPK}

$36(24.7 \%)$

$13(8.9 \%)$

$69(47.3 \%)$

$18(12.3 \%)$

$10(6.8 \%)$

$0(0 \%)$

$5(5.6 \%)$

$10(11.1 \%)$

$19(21.1 \%)$

$25(27.8 \%)$

$31(34.4 \%)$

$28(19.3 \%)$

$47(32.4 \%)$

$66(45.5 \%)$

$4(2.8 \%)$

$70(56.9 \%)$

$4(3.3 \%)$

$6(4.9 \%)$

$43(35 \%)$

$71(49.3 \%)$

$30(20.8 \%)$

$43(29.9 \%)$

\section{TBSPK}

$58(24.6 \%)$

$17(7.2 \%)$

$57(24.2 \%)$

$100(42.4 \%)$

$4(1.7 \%)$

$0(0 \%)$

$2(1.2 \%)$

$15(8.8 \%)$

$47(27.6 \%)$

$46(27.1 \%)$

$60(35.3 \%)$

$47(20.2 \%)$

$80(34.3 \%)$

$95(40.8 \%)$

$11(2.7 \%)$

$128(58.4 \%)$

$19(8.7 \%)$

$13(5.9 \%)$

$59(26.9 \%)$

$147(62.3 \%)$

$37(15.7 \%)$

$52(22 \%)$

\section{Items}

**Hired works

Cleaning/area preparation $(17.4 \%)$

Cultivation (14.7\%)

Fertilization (14.7\%)

Weeding (17.7\%)

Harvesting $(23.0 \%)$

FFB sales (12.5\%)

\section{Experience in cultivating oil palm}

No experience $(3.1 \%)$

$1-10$ yrs $(55.1 \%)$

\section{TSSPK}

$52(16.9 \%)$

$44(14.3 \%)$

$41(33.3 \%)$

$55(17.9 \%)$

$73(23.8 \%)$

$42(13.7 \%)$

-

$33(22.6 \%)$

\section{TBSPK}

$72(17.7 \%)$

$61(15.0 \%)$

$64(15.8 \%)$

$71(17.5 \%)$

$91(22.4 \%)$

$47(11.6 \%)$

$12(5.1 \%)$

$177(73.3 \%)$ 
$11-20$ yrs $(18.6 \%)$

$21-30$ yrs $(15.7 \%)$

$31-40$ yrs $(7.3 \%)$

\section{Planting Density}

$136 \mathrm{palms} / \mathrm{ha}$

$148 \mathrm{palms} / \mathrm{ha}$

$160 \mathrm{palm} / \mathrm{ha}$

**Reason for cultivating oil palm

Interest (36.4\%)

Occupy spare time $(2.4 \%)$

Hereditary heritage $(8.3 \%)$

Source of income $(50.8 \%)$

Others $(2.0 \%)$

Note:

** respondents could choose more than one answer
$44(30.1 \%)$

$50(34.2 \%)$

$19(13.0 \%)$

$89(62.24 \%)$

$37(25.87 \%)$

$17(11.89 \%)$

$64(29.9 \%)$

$5(2.3 \%)$

$31(14.5 \%)$

$110(51.4 \%)$

$4(1.9 \%)$
$103(44.98 \%)$

$97(42.36 \%)$

$29(12.66 \%)$

DOI 10.35631/IJMTSS.3140011

$27(11.5 \%)$

$10(4.3 \%)$

$9(3.8 \%)$

$133(40.7 \%)$

$8(2.4 \%)$

$14(4.3 \%)$

$165(50.5 \%)$

$7(2.1 \%)$

\section{Fresh Fruit Bunches (FFB) Yield of Scheme Participants}

The acreage of the farm and the yield of FFB are crucial elements in the study. Table 5 shows the average farm size for TSSPK before replanting for the three states that were smaller than 2.00ha. The acreage is still smaller than the economic acreage of 4 hectares (Idris, 2012).

Table 5: Proportion of TSSPK Participants' Farm Size Before Replanting

\begin{tabular}{|l|c|c|c|c|}
\hline Farm Size & Johor & Sabah & Sarawak & Total \\
\hline $0.00-2.00 \mathrm{ha}$ & 28 & 92 & 138 & $258(79.38 \%)$ \\
\hline $2.01-4.00 \mathrm{ha}$ & 3 & 26 & 3 & $32(9.85 \%)$ \\
\hline 4.01-6.00ha & 1 & 21 & 4 & $26(8.00 \%)$ \\
\hline$>6.00 \mathrm{ha}$ & 1 & 8 & 0 & $9(2.77 \%)$ \\
\hline
\end{tabular}

The result shows that the majority of the TSSPK respondents own farm size smaller than $2 \mathrm{ha}$ (Table 5). The $1^{\text {st }}$ and $2^{\text {nd }}$ year of FFB yield also fall into the low category, smaller than 4.60ha/t/year (93.52\% and 95.3\% respectively). As mention above, the data was collected in 2016 with the occurrence year of El-Nino. Sabah was the most affected state and registered a decline of $14.5 \%$ to $17.10 \mathrm{t} / \mathrm{ha} /$ year as against $19.99 \mathrm{t} / \mathrm{ha} /$ year in the year 2015 . Since the respondents of TSSPK were mostly from Sabah, the low FFB yield was expected and reflecting the El-Nino phenomenon (Table 6).

Table 6: Farm Size and FFB Yield of TSSPK Participants

$\begin{array}{ll}\text { 1st-year } & \text { Farm size } \\ \text { FFB yield } & 0.00-2.00 \mathrm{ha} \\ & 2.01-4.00 \mathrm{ha} \\ & 4.01-6.00 \mathrm{ha} \\ & >6.00 \mathrm{ha}\end{array}$

FFB yield (t/ha/yr)

Low $(0.00-4.60)$

Medium (4.61-8.00)

Johor
20
6
2
0

5

0

Sabah
43
22
14
4

Sarawak
10
3
5
0

Total

$73(56.59 \%)$

$31(24.03 \%)$

$21(16.28 \%)$

$4(3.10 \%)$

$101(93.52 \%)$

$4(3.70 \%)$ 


\begin{tabular}{llcccc}
\hline 2nd-year & Farm size & & & & \\
FFB yield & $0.00-2.00 \mathrm{ha}$ & 15 & 46 & 15 & $76(62.3 \%)$ \\
& $2.01-4.00 \mathrm{ha}$ & 6 & 21 & 0 & $27(22.13 \%)$ \\
& $4.01-6.00 \mathrm{ha}$ & 0 & 13 & 3 & $16(13.11 \%)$ \\
& $>6.00 \mathrm{ha}$ & 0 & 3 & 0 & $3(2.46 \%)$ \\
& FFB yield (t/ha/yr) & & & & \\
& Low (0.00-8.80) & 19 & 81 & 18 & $118(95.3 \%)$ \\
& Medium (8.81-12) & 1 & 1 & 0 & $2(1.63 \%)$ \\
& High $(12.01-15.50)$ & 2 & 1 & 0 & $3(2.44 \%)$ \\
\hline
\end{tabular}

The number of TBSPK and TSSPK respondents owning a farm size smaller $2 \mathrm{ha}$ was almost similar (Table 7). However, for Sarawakian respondent, one-third of the total respondent owned a farm between 2 to 4 ha. The $1^{\text {st }}$ and $2^{\text {nd }}$ year of FFB yield also shows the same trend with TSSPK respondent.

Table 7: Farm Size and FFB Yield of TBSPK Participants

\begin{tabular}{|c|c|c|c|c|c|}
\hline 1st-year & Farm size & Johor & Sabah & Sarawak & Total \\
\hline \multirow[t]{8}{*}{ FFB yield } & $0.00-2.00 \mathrm{ha}$ & 7 & 28 & 86 & $121(59.90 \%)$ \\
\hline & 2.01-4.00ha & 3 & 17 & 32 & $52(25.74 \%)$ \\
\hline & 4.01-6.00ha & 1 & 15 & 6 & $22(10.89 \%)$ \\
\hline & $>6.00 \mathrm{ha}$ & 0 & 4 & 3 & $7(3.47 \%)$ \\
\hline & \multicolumn{5}{|l|}{ FFB yield (t/ha/yr) } \\
\hline & Low $(0.00-4.60)$ & 3 & 62 & 123 & $188(96.41 \%)$ \\
\hline & Medium (4.61-8.00) & 0 & 2 & 4 & $6(3.08 \%)$ \\
\hline & High (8.01-10.50) & 1 & 0 & 0 & $1(0.51 \%)$ \\
\hline 2nd-year & Farm size & & & & \\
\hline \multirow[t]{8}{*}{ FFB yield } & $0.00-2.00 \mathrm{ha}$ & 14 & 45 & 100 & $159(76.44 \%)$ \\
\hline & $2.01-4.00 \mathrm{ha}$ & 3 & 7 & 23 & $33(15.87 \%)$ \\
\hline & 4.01-6.00ha & 0 & 12 & 3 & $15(7.21 \%)$ \\
\hline & $>6.00 \mathrm{ha}$ & 0 & 0 & 1 & $1(0.48 \%)$ \\
\hline & \multicolumn{5}{|l|}{ FFB yield (t/ha/yr) } \\
\hline & Low $(0.00-8.80)$ & 7 & 63 & 127 & $197(99.49 \%)$ \\
\hline & Medium (8.81-12) & 0 & 1 & 0 & $1(0.51 \%)$ \\
\hline & High (12.01-15.50) & 0 & 0 & 0 & $0(0 \%)$ \\
\hline
\end{tabular}

\section{The income of TSSPK and TBSPK Scheme Participants}

Based on Table 8, there was an increased in income from the FFB sales after participating in the scheme. For the lower-income category, the percentage was reduced to $30.11 \%$. For the percentage in the higher category, the income was increased between $2.66 \%$ to $16.59 \%$ after joining the scheme. There is an upward trend of palm oil price, and the high pace was in the second half of the year 2016, with the monthly average price at RM 3200/t in December 2016. Copyright (C) GLOBAL ACADEMIC EXCELLENCE (M) SDN BHD - All rights reserved 
Therefore, in line with the price trend, ISH also enjoyed the short term price rose before fall back after April 2017 (Figure 3).

Table 8: Information on Income from Oil Palm Farming

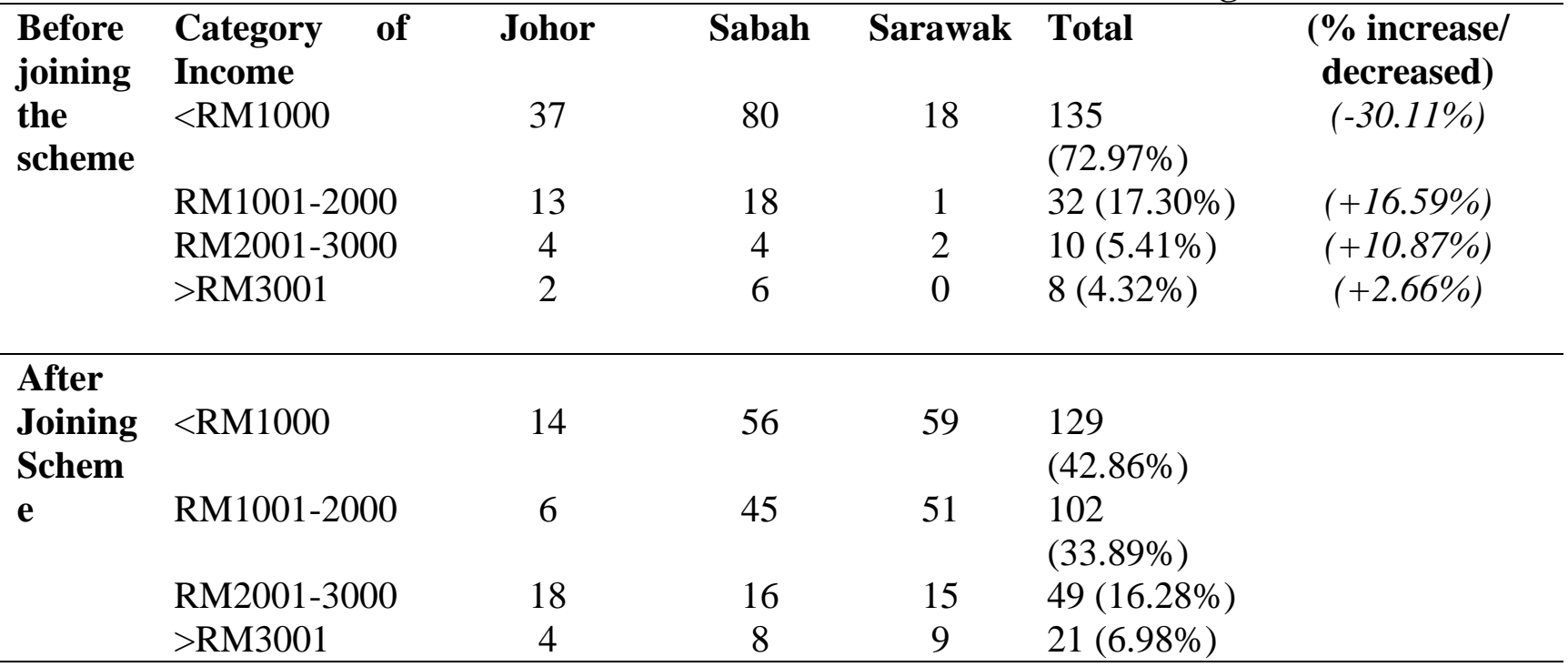

Figure 3: Trend of Crude Palm Oil (CPO) Price, 2017 vs 2016

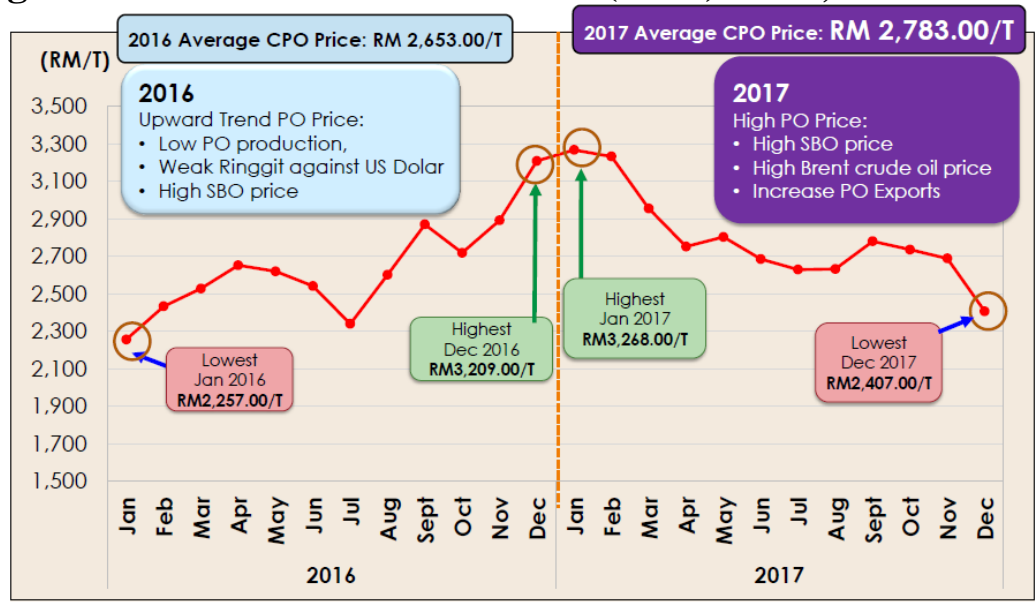

Source: Kushairi (2018)

\section{Crops and Livestock Integration Activity}

About $34(8 \%)$ respondents out of the total respondents have implemented livestock and crop integration activity. The most popular crops are pineapple (29\%) followed by banana $(21 \%)$ and vegetables (9\%). For the livestock, they reared goat for integration (6\%) (Table 9). Most of the participants stated that this activity is only for their consumption and as an alternative income. From this number, it shows that farming oil palm was the main sources of income to most of the respondents. Accordingly, this integration activity is highly recommended to support and overcome issues of lost income during oil palm immature period. 
Table 9: Information on Crop and Livestock Integration Activity

\begin{tabular}{llcc}
\hline Integration & Types & Frequency & Percentage \\
\hline Livestock & Goat & 6 & $18 \%$ \\
Crops & Chilli & 2 & $6 \%$ \\
& Pineapple & 10 & $29 \%$ \\
& Paddy & 1 & $3 \%$ \\
& Banana & 7 & $21 \%$ \\
& Vegetable & 3 & $9 \%$ \\
& Sugarcane & 1 & $3 \%$ \\
& Corn & 1 & $3 \%$ \\
& Pumpkin & 1 & $3 \%$ \\
& Watermelon & 1 & $3 \%$ \\
& Cassava & 1 & $3 \%$ \\
& Total & $\mathbf{3 4}$ & $\mathbf{1 0 0 \%}$ \\
\hline
\end{tabular}

\section{The Good Agricultural Practices (GAP)}

Some items which were related to the adoption of the Good Agricultural Practices (GAP) was asked in the questionnaire. Four scores were assigned, and the details for each score is shown in Table 10 and Table 11. The comparison before and after joining TSSPK scheme was inquired to determine the effect of extension services given by the extension agents during the implementation of the scheme.

For TSSPK scheme, it was shown that many participants were practising GAP after joining the scheme. The increase in percentage for GAP practices such as cultivation system was $17.84 \%$, monitoring of nutrient deficiency $15.16 \%$, disease monitoring $12.24 \%$ and apply fertilisers around the tree $11.64 \%$. Based on the researched states, Sabah has the highest increase in percentage after joining the scheme by $15.81 \%$, followed by Sarawak by $13.24 \%$ and Johor at $4.60 \%$. This finding demonstrated the effectiveness of the extension services by TUNAS Officers in guiding the smallholders, especially on the oil palm management practices. The percentages of participants who implemented the GAP at Johor was already high $(94.53 \%)$ before joining the scheme (Sheilyza, 2016). Thus, the difference in GAP practices after participated in the scheme was not very significant.

For the participants of TBSPK, the majority of them were complied with GAP after implementing the scheme (Table 11). The GAP was introduced to smallholders, who newly open their land for the cultivation of oil palm. It can be concluded that the objective of introducing GAP to the scheme participants has been achieved. The result also showed that the percentages of GAP compliance, according to states, was dominated by Johor (98.15\%) followed by Sarawak (88.84\%) and Sabah (87.58\%). However, the percentages for noncompliant GAP were high in Sabah (12.42\%) and Sarawak (11.16\%). The geographically scattered participants in Sabah and Sarawak was possibly one of the factors, causing them to be outdated from the group, or they are possibly late adopters 
Table 10: Good Agricultural Practices (GAP) for TSSPK Participants

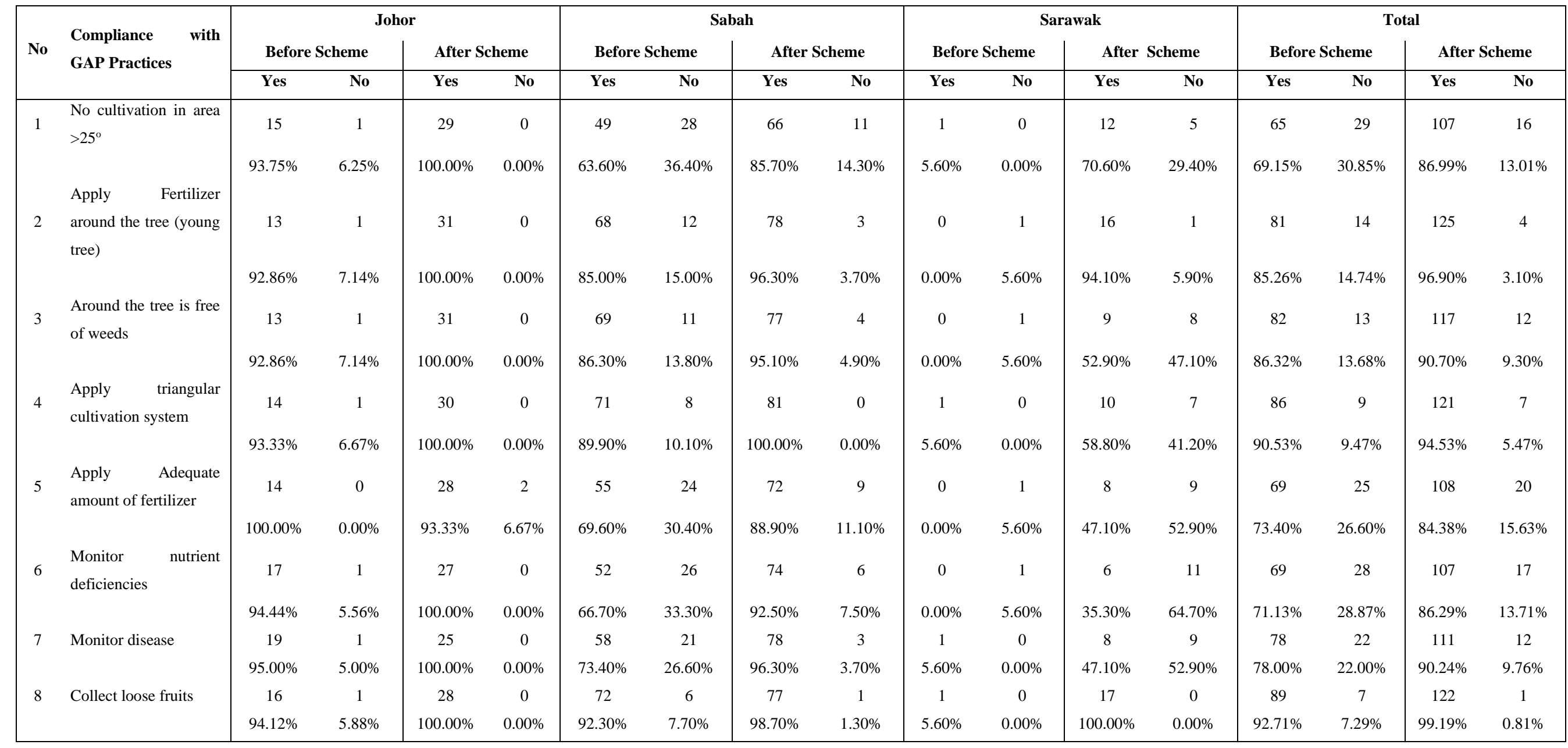

Copyright $\odot$ GLOBAL ACADEMIC EXCELLENCE (M) SDN BHD - All rights reserved 


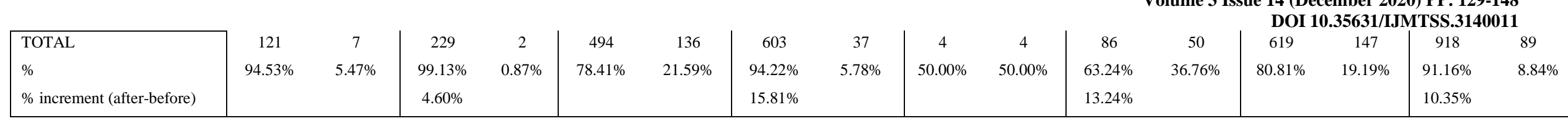


Volume 3 Issue 14 (December 2020) PP. 129-148

\begin{tabular}{|c|c|c|c|c|c|c|c|c|c|}
\hline \multirow{3}{*}{ No } & \multirow{3}{*}{ Compliance with GAP Practices } & \multirow{2}{*}{\multicolumn{2}{|c|}{$\begin{array}{c}\text { Johor } \\
\text { After Scheme }\end{array}$}} & \multirow{2}{*}{\multicolumn{2}{|c|}{$\begin{array}{c}\text { Sabah } \\
\text { After Scheme }\end{array}$}} & \multirow{2}{*}{\multicolumn{2}{|c|}{$\begin{array}{c}\text { Sarawak } \\
\text { After Scheme }\end{array}$}} & \multirow{2}{*}{\multicolumn{2}{|c|}{$\begin{array}{c}\text { DOI 10.35631/IJMTSS.3 } \\
\text { Total } \\
\text { After Scheme }\end{array}$}} \\
\hline & & & & & & & & & \\
\hline & & Yes & No & Yes & No & Yes & No & Yes & No \\
\hline \multirow[t]{2}{*}{1} & No cultivation in area $>250$ & 20 & 0 & 38 & 19 & 98 & 25 & 156 & 44 \\
\hline & & $100.00 \%$ & $0.00 \%$ & $66.67 \%$ & $33.33 \%$ & $79.67 \%$ & $20.33 \%$ & $78.00 \%$ & $22.00 \%$ \\
\hline \multirow[t]{2}{*}{2} & $\begin{array}{l}\text { Fertilization around the tree (young } \\
\text { tree) }\end{array}$ & 20 & 1 & 57 & 1 & 119 & 6 & 196 & 8 \\
\hline & & $95.24 \%$ & $4.76 \%$ & $98.28 \%$ & $1.72 \%$ & $95.20 \%$ & $4.80 \%$ & $96.08 \%$ & $3.92 \%$ \\
\hline \multirow[t]{2}{*}{3} & Around the tree is free of weeds & 20 & 0 & 50 & 8 & 107 & 19 & 177 & 27 \\
\hline & & $100.00 \%$ & $0.00 \%$ & $86.21 \%$ & $13.79 \%$ & $84.92 \%$ & $15.08 \%$ & $86.76 \%$ & $13.24 \%$ \\
\hline \multirow[t]{2}{*}{4} & $\begin{array}{l}\text { Application of triangular cultivation } \\
\text { system }\end{array}$ & 19 & 0 & 57 & 1 & 119 & 6 & 195 & 7 \\
\hline & & $100.00 \%$ & $0.00 \%$ & $98.28 \%$ & $1.72 \%$ & $95.20 \%$ & $4.80 \%$ & $96.53 \%$ & $3.47 \%$ \\
\hline \multirow[t]{2}{*}{5} & Adequate fertilization & 20 & 2 & 46 & 12 & 99 & 22 & 165 & 36 \\
\hline & & $90.91 \%$ & $9.09 \%$ & $79.31 \%$ & $20.69 \%$ & $81.82 \%$ & $18.18 \%$ & $82.09 \%$ & $17.91 \%$ \\
\hline \multirow[t]{2}{*}{6} & Monitor nutrient deficiencies & 20 & 0 & 53 & 5 & 110 & 13 & 183 & 18 \\
\hline & & $100.00 \%$ & $0.00 \%$ & $91.38 \%$ & $8.62 \%$ & $89.43 \%$ & $10.57 \%$ & $91.04 \%$ & $8.96 \%$ \\
\hline \multirow[t]{2}{*}{7} & Monitor disease & 21 & 0 & 51 & 6 & 110 & 15 & 182 & 21 \\
\hline & & $100.00 \%$ & $0.00 \%$ & $89.47 \%$ & $10.53 \%$ & $88.00 \%$ & $12.00 \%$ & $89.66 \%$ & $10.34 \%$ \\
\hline \multirow[t]{2}{*}{8} & Collect loose fruits & 19 & 0 & 50 & 5 & 122 & 5 & 191 & 10 \\
\hline & & $100.00 \%$ & $0.00 \%$ & $90.91 \%$ & $9.09 \%$ & $96.06 \%$ & $3.94 \%$ & $95.02 \%$ & $4.98 \%$ \\
\hline & TOTAL & 159 & 3 & 402 & 57 & 884 & 111 & 1445 & 171 \\
\hline
\end{tabular}

Copyright $\odot$ GLOBAL ACADEMIC EXCELLENCE (M) SDN BHD - All rights reserved 


\section{Extension Services by the TUNAS Officers}

Table 12 showed that about $90.24 \%$ of the participants had received advice from by TUNAS Officers. $75.4 \%$ of participants have attended courses, seminars and workshops organised by MPOB. There were high numbers of participants in Sarawak $(14.58 \%)$ who did not get extension services. It is due to the nature of Sarawakian who reside in the Long House. The local leader or Tuai Rumah took over the communication with MPOB staff due to large numbers of them and the language barrier. Thus, during the study, it was found that most of the respondents in the Long House were not aware of the GAP or extension services available for them.

Improvement needs to be made in the future so that each participant manage to receive extension services and attend courses organised by MPOB as to ensure related technologies can be implemented effectively by the smallholders (Hayrol, 2010). Relevant ICT could be used to improve the technology transfer process (Ali, M., Man, N., Farrah, M. M. and Omar, S. Z., 2020).

Table 12: Extension Services By Tunas

\begin{tabular}{c|c|cc|cc|cc|cc}
\hline TUNAS & Received/ & \multicolumn{2}{|c|}{ Johor } & \multicolumn{2}{c|}{ Sabah } & \multicolumn{2}{c|}{ Sarawak } & \multicolumn{2}{c}{ Total } \\
Services & Attended & Freq & \% & Freq & \% & Freq & \% & Freq & \% \\
\hline Extension & Yes & 84 & $93.33 \%$ & 135 & $93.10 \%$ & 123 & $85.42 \%$ & 342 & $90.24 \%$ \\
services & No & 6 & $6.67 \%$ & 10 & $6.90 \%$ & 21 & $14.58 \%$ & 37 & $9.76 \%$ \\
\hline \multirow{2}{*}{ Courses } & Yes & 60 & $66.67 \%$ & 104 & $72.22 \%$ & 121 & $84.03 \%$ & 285 & $75.40 \%$ \\
& No & 30 & $33.33 \%$ & 40 & $27.78 \%$ & 23 & $15.97 \%$ & 93 & $24.60 \%$ \\
\hline
\end{tabular}

\section{Evaluation Implementation of Scheme by MPOB as Executor}

This study also concluded evaluating the participants towards the scheme and MPOB as the implementer agency. This information (Table 13) is essential for MPOB to measure the efficiency of the implementation schemes, which include the allocation, the quality of agricultural inputs distribution as well as the services and policies created. Based on the results, the participants were overwhelmingly satisfied with the argument that this scheme will help them minimise production costs (4.29), and the scheme offers advantages for smallholders (4.41).

Respondents were also pleased with the services by implementer agency offered by MPOB. They agreed with the argument that they are confident of MPOB's ability to assist smallholder farmers (4.35). The supply of inputs was sufficient and quick (3.96), the application method was easy (3.90), they received quality agricultural inputs (4.27), and they received agricultural inputs on time (3.76).

Most respondents were also satisfied with the extension services given by the TUNAS Region Officers. On average, respondents agreed with positive statements related to the TUNAS services. 
Table 13: Evaluation Implementation of Scheme by MPOB as Executor

Volume 3 Issue 14 (December 2020) PP. 129-148 DOI 10.35631/IJMTSS.3140011

\begin{tabular}{|c|c|c|c|c|c|}
\hline & \multirow{2}{*}{\multicolumn{4}{|c|}{ Mean Score }} \\
\hline & & & & & \\
\hline & & \multirow[t]{2}{*}{ Johor } & \multirow[t]{2}{*}{ Sabah } & \multirow[t]{2}{*}{ Sarawak } & \multirow[t]{2}{*}{$\begin{array}{l}\text { Total } \\
\text { Average }\end{array}$} \\
\hline \multicolumn{2}{|r|}{ Satisfaction towards the scheme } & & & & \\
\hline 1 & EPP1 scheme can reduce the cost of purchasing inputs. & 4.29 & 4.31 & 4.27 & 4.29 \\
\hline 2 & This scheme provides an advantages to the smallholders. & 4.42 & 4.46 & 4.34 & 4.41 \\
\hline \multicolumn{6}{|c|}{ Assessment towards MPOB as executor } \\
\hline 3 & I am confident in the ability of MPOB in supporting smallholders through EPP1 scheme. & 4.37 & 4.42 & 4.27 & 4.35 \\
\hline 4 & This program is carried out continuously by MPOB. & 4.48 & 4.37 & 4.26 & 4.37 \\
\hline 5 & The distribution of seedlings is efficient. & 4.16 & 3.82 & 3.91 & 3.96 \\
\hline 6 & The application process is easy & 4.24 & 3.89 & 3.57 & 3.90 \\
\hline 7 & The scheme provided quality seedlings, fertilisers and chemical pesticides. & 4.33 & 4.26 & 4.22 & 4.27 \\
\hline 8 & Participants receive agricultural inputs on time. & 3.92 & 3.72 & 3.65 & 3.76 \\
\hline \multicolumn{6}{|c|}{ Evaluation towards TUNAS as an extension agent } \\
\hline 9 & TUNAS officer was cooperative in the application process and distribution of inputs. & 4.47 & 4.44 & 4.3 & 4.40 \\
\hline & TUNAS officer has good and well experienced in the field of oil palm cultivation & 4.36 & 4.44 & 4.31 & 4.37 \\
\hline & TUNAS officers are honest and responsible with their duties & 4.42 & 4.47 & 4.28 & 4.39 \\
\hline & I am satisfied with the supervision and extension services provided by TUNAS Officers. & 4.39 & 4.43 & 4.32 & 4.38 \\
\hline & TUNAS officers have regularly organised related courses to disseminate information on oil palm management & 4.01 & 4.17 & 4.01 & 4.06 \\
\hline
\end{tabular}




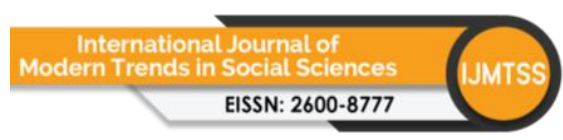

Volume 3 Issue 14 (December 2020) PP. 129-148

DOI 10.35631/IJMTSS.3140011

\section{Conclusion and Recommendation}

In general, participants who involved in the TSSPK and TBSPK schemes are mostly older and the farm owner. Respondents also received formal education whether at the primary, secondary, college and university. However, some oil palm management activities which required machinery, energy and skills have been handed over to the appointed contractors such as land clearing, planting of seedlings and harvesting of FFB. The result showed that most of the participants owned oil palm farm smaller than the economic size of 4 ha. The FFB yield for the 1 st and 2 nd year of harvesting was in a low category and smaller than $4.06 /$ ha/year. This is due to the data collection that was conducted in 2006 when El Nino hit the country.

Income from oil palm for participants much depended on FFB yield and the CPO price. Even though FFB yield declined in 2016, the higher trend of CPO price has help participant to get high income in the short period. Some participants have cultivated crops integration in their plantation to get additional income. From this study, it also showed that many participants adopted the GAP after joining the scheme. However, high numbers of smallholders do not comply with the GAP in Sabah and Sarawak. This study also showed that most of the respondents received extension services and attended courses. In specific areas, especially in Sarawak, some of the participants did not attend any courses provided by MPOB due to location. Participants were satisfied with the implementation of the scheme implemented by MPOB as well as extension services provided by the TUNAS Officers. The result also showed that this scheme is relevant to smallholders and recommended to be implemented in the future.The study, therefore, makes the following recommendations: -

\section{Allocation Of Agricultural Inputs And Cost For Land Preparation Need To Be Increased. The Distribution Methods Of The Inputs Still Can Be Improved}

The inputs given to the participants should follow the timeline or period stated in the Operational Procedure. However, in the actual implementation, something can happen disorderly, and it will delay the agriculture input delivery, thus, affecting the performance of oil palm cultivation need proper planning and accurate time for fertiliser application and the weeding. Therefore, innovative approaches should replace the traditional or bureaucracy system to deliver input. Currently, chemical voucher and fertiliser coupon were introduced and implemented.

\section{The Clustering Of The Smallholders Into Organised Cooperatives}

Independent smallholders are scattered geographically, disorganised and highly dependent on a middleman to manage their farm and send FFB to mills. Currently, the ratio of extension officer (TUNAS) to the smallholders were too big; it is difficult for TUNAS to reach smallholders to disseminate the information and technologies. Therefore, it is recommended that independent smallholders be clustered and managed by an organised cooperative. The cooperative will extend support services, act as a purchasing agent of crucial inputs, assist in negotiating a long-term contract with the FFB mils to get a better price and to deal business with agriculture input producers for reasonable price wholesale purchase. The more important thing is by clustering them into a cooperative, the task for extension services such as best practice (GAP, MSPO, and RSPO) and certification will be much easier. 
Smallholders Apply Crop Or Livestock Integration To Support The Loss Of Income During The Unproductive Period Of A Palm Tree And Continuity Of GAP Implementation

Several studies have proven that crop integration with oil palm is the best way to address the issue of the lost income during the immature phase of oil palm growing after replanting. This activity is defined as value-farming, which involves the planting of cash crops, rearing of livestock together with industrial crop areas such as oil palm and others. By implementing this activity, it could maximise the land use and contribute additional income to the independent smallholders. Furthermore, the establishment cost for crop integration could be share with the development cost of oil palm replanting or new planting. Therefore, the total development cost could be reduced. Smallholders low productivity in FFB yield is related to their low capital to manage their farm, especially on fertiliser application. Therefore, GAP practices need to be implemented thoughtfully by the smallholders. The ignorance of GAP implementation will lead to the poor performance of their farm in the future (Fauziah, 2020).

\section{Study The Impact Of The Scheme On The Mature Palm}

Further study on the impact of this scheme after the palm is useful, valuable, and the information is needed by the oil palm industry to evaluate the actual cost-benefit from the allocated grant for NKEA-Oil Palm (EPP1).

\section{References}

Ali, M., Man, N., Farrah, M. M., and Omar, S. Z. (2020). Factors influencing behavioral intention of farmers to use ICTs for agricultural risk management in Malaysia. Pakistan Journal of Agricultural Research, 33(2), 295-302.

Ali, Z. A. N., Siti, M. A., Balu, N., Ainul, S. S., Norhidayu, A., Nur and A. H., (2017). An Economic Study on Technical Efficiency among Independent Smallholders in Sabah \& Sarawak. Proceeding of Palm Oil Economic Review \& Outlook Seminar 2017. 17 January 2017.

Fauziah Arshad; Siti Mashani Ahmad; Kamalrudin Mohamed Salleh; Khairuman Hashim; Mohd Shahrin Rahami; Balu Nambiappan and Azman Ismail (2020) A Comparative Analysis of Agricultural Practices, Costs and Yields of Pre- and Post-Malaysian Sustainable Palm Oil (MSPO) Certification for Independent Smallholders in Malaysia. Oil Palm Industry Economic Journal. Vol. 20 (1) March 2020 p. 36 - 44

Fauziah, A.; Siti, M. A.; Ayatollah, K.; Anis, M.; Raja, Z. R. O. and Zulkifli, A. M. (2018). Economic Benefits of Oil Palm Replanting In Oil Palm Replanting: Little Steps to A Giant Leap. P79-95. Kajang, Selangor. Malaysian Palm Oil Board.

Hasnah, Fleming, E. and Coelli, T. (2004). Assessing the Performance of a Nucleus Estate and Smallholder Scheme for Oil Palm Production in West Sumatra: A Stochastic Frontier Analysis. Agricultural Systems, 79(1), 17-30. doi:http://dx.doi.org/10.1016/S0308521X(03)00043-X

Hayrol, A. M. S.; Azizan, A. and Azahari, I. (2010). The Ninth Malaysian Plan and Agriculture Extension Officer Competency: A Combination for Intensification of Paddy Industry in Malaysia. The Journal of International Social Research Volume 3/10 Winter 2010

Idris, O; Azman, I and Chang, C. C. (2001). Improving Productivity: The Replanting Imperative. Oil Palm Industry Economic Journal, Vol.1 (1): 21-27

Ismail, A. and Mamat, M. N. (2002). The optimal age of oil palm replanting. Oil Palm Industry Economic Journal, 2(1), 11-18.

Jasmin, A. S; Azizan, A. and Azahari, I. (2013). Roles of Extension Agents towards Agricultural Practice in Malaysia. International Journal on Advanced Science Engineering Information Technology. Vol 3 (1): 59-63. 
Kushairi, A (2013), Oil Palm Biology: Facts \& Figures, pg. 67.

Mohamad, R.B, Wibawa, W., Mohayidin, M.G., Puteh, A.B., Juraimi, A.S., Awang, Y. and Lassim, M.B.M (2010). Management of Mixed Weeds in Young Oil-Palm Plantation with Selected Broad-Spectrum Herbicides. Pertanika J. Trop. Agric. Sci. 33(2): 193203.

MPOB (2016). Project Implementation Unit (PIU): Achievement in 2015. Integration Research and Extension Division (IRED). MPOB Operational Plan 2016. Volume 1: Research Division. pp 206-209

MPOB (2020). Factsheet of Independent Smallholder June 2020. Smallholders Research and Development Division. Malaysia Palm Oil Board.

National Transformation Programme Annual Report 2017 (2017), Retrieved from http://www.mampu.gov.my/images/pengumuman/NTP_AR2017_ENG.pdf

Nurhanani, M., Nazirah, C.J., Ainul, S.S., Mohamad, A. J., Amran, A., Nursuhana, D., Parthiban, K., Tan, S.P., Hasmiza, D., Khairul, A., Shakir, A., Mohd, K. A. I. and Hamdan, A.B. (2016). Adoption of Good Agriculture Practices (GAP) Among Independent Smallholders in Malaysia. Poster Proceeding of National Independent Oil Palm Smallholders Conference 2016. pp. 169-183.

Parveez, G. K. A. (2020). Malaysia Oil Palm Industry Performance 2019 and Prospects for 2020 [PowerPoint Slides]. Palm Oil Economic \& Outlook Seminar 2020. 16 January 2020, Sheraton Imperian, Kuala Lumpur.

Rahim M. S. (2008). Competency and Practice of Education Development (Concept and Practice of Extension Education). Extension Bulletin, No. 1, Universiti Putra Malaysia.

Rahim M. S. (2010). Empowering of Agricultural Extensionists through Knowledge and Skill of the Extension Profession.

Sheilyza, M. I and Zulkifli, A.M. (2020). Influence of Knowledge, Attitude and Skill on Good Agriculture Practices of Seedling Assistance Scheme Participant toward Oil Palm Production in Sabah and Sarawak. Oil Palm Industry Economic Journal (OPIEJ). Vol. 20 (1) March 2020 p. $12-20$

Sheilyza, M. I and Zulkifli, A.M. (2016). Preliminary Evaluation of EPP1 Outcome: Oil Palm Replanting and New Planting Scheme. 11-12 October 2016. Oral Proceeding of National Independent Oil Palm Smallholders Conference 2016. Pp 86-97.

Zaki Aman; Humaira Mat Taib; Sheilyza Ishak; Amran Ariffin; Ainul Shazwin; Abdul Rahman Abdul Rahim and Ramle Moslim (2020).Factors Influencing Fertiliser Purchase Intention among the Oil Palm Independent

Zulkifli Abd Manaf; Ayat K Ab Rahman; Nurul Aimi Abd Halim; Suboh Ismail and Ramli Abdullah (2013). Assessment of the Oil Palm Seedlings Assistance Scheme on Fresh Fruit Bunch Yield and Income of Smallholders. Oil Palm Industry Economic Journal. $35-44$.

Zulkifli, A. M.; Parthiban, K., Sheilyza, M.I. and Humaira, M.T (2018). Socio-Economic of Oil Palm Replanting by Independent Smallholders in Oil Palm Replanting: Little Steps to a Giant Leap. P79-95. Kajang, Selangor. Malaysian Palm Oil Board. 